\title{
Performance in blue fox (Vulpes lagopus) fed low-protein diets supplemented with DL-methionine and L-histidine
}

\author{
Vappu Ylinen ${ }^{1}$, Päivi Pylkkö2${ }^{2}$, Jussi Peura ${ }^{3}$, Essi Tuomola ${ }^{3}$ and Jarmo Valaja ${ }^{1}$ \\ ${ }^{1}$ Department of Agricultural Sciences, Koetilantie 5, 00014 University of Helsinki, Finland \\ ${ }^{2}$ Kannus Research Farm Luova Ltd., Turkistie 6, 69100 Kannus, Finland \\ ${ }^{3}$ Finnish Fur Breeders Association, Martinkyläntie 48, 01601 Vantaa, Finland \\ e-mail: vappu.ylinen@helsinki.fi
}

\begin{abstract}
The effects of low-protein diets supplemented with DL-methionine (MET) and L-histidine (HIS) on growth, pelt size and pelt quality were studied in two performance trials conducted at the Kannus Research Farm Luova Ltd, Finland. Both trials were conducted with 200 blue foxes, caged male-female pairs, initial age on average 20 weeks (trial 1) and 25 weeks (trial 2). In trial 1, diets contained digestible crude protein (DCP) $24 \%, 20 \%$ and $16 \%$ of metabolisable energy (ME). In trial 2, diets contained DCP $20 \%, 16.5 \%$ and $13 \%$ of ME. In both trials, the middle protein level was fed with or without MET and the lowest protein level was fed with MET and with or without HIS. In trial 1, blue foxes showed the greatest average daily gain (ADG) in the highest protein diet. Pelt size and pelt quality were not affected. In trial 2, blue foxes showed the greatest ADG in the low-protein groups. Pelt size and pelt quality were not affected.
\end{abstract}

Key words: fur animal, protein level, amino acids, growth, pelt size, pelt quality

\section{Introduction}

The current recommendation for dietary protein for blue fox (Vulpes lagopus) in the growing-furring period (from September 1 to pelting) is a minimum of $26 \%$ of metabolisable energy (ME) (NRC 1982, MTT 2006). This recommendation is based on research done 40 years ago with animals genetically different, especially in size (Rimeslåtten 1976, Hansen et al. 1991). The size of the modern blue fox has dramatically increased in recent decades, which may have influenced the animal's nutrient requirements (Dahlman 2003). Still, feed composition should be balanced so that the animal's dietary requirements are fulfilled but no over- or under-feeding occurs. Over-feeding of protein is especially unwise, since high-quality protein is often the most expensive feed ingredient, and the availability of high-quality protein feeds such as fish, fishmeal, and bone-free slaughter by-products varies. Although blue foxes as carnivores are well able to use glucogenic amino acids as energy sources, their use is not energy efficient, because conversion of toxic ammonia to urea consumes energy. The efficiency of ME for energy gain is higher in low-protein diets (Bellego et al. 2001). The conversion of dietary protein to body fat is energetically the most inefficient process, especially in the growing-furring season when body fat deposition is dominant in blue fox (Tauson 2012). Furthermore, the additional protein in feed increases environmental emissions, since excess ammonia is excreted in urine. Lowering the dietary protein level results in lower N emissions (Dahlman et al. 2002a).

Research by Dahlman (2003) has shown that lower dietary protein, especially in the growing-furring period is sufficient for blue fox. Dahlman (2007) stated that the protein recommendations for blue fox may be too high and that dietary protein levels 20-22\% of ME would be adequate. Accordingly, Nordic Association of Agricultural Scientists has lowered its dietary protein recommendation for blue fox in the late growing-furring season from $26 \%$ of ME to a minimum of $24 \%$ of ME and The Finnish Fur Breeders' Association to a minimum of $22 \%$ of ME (Hansen et al. 1991, Finne 2006, Lassén et al. 2012). In the present study, we lowered the dietary protein to $13-16 \%$ of ME in the late growing-furring season when blue fox have reached full maturity. In the late growing-furring season when the increment in size of modern blue fox is mainly fat, the proportion of body muscle is smaller. Therefore, a lower dietary protein requirement may be reasonable (Dahlman 2003).

The protein requirement of monogastric animals is actually requirements for amino acids. In the ideal protein, in which the ratio among essential amino acids equals the animal's amino-acid requirements, the animal's requirement for crude protein is least, and no excess $\mathrm{N}$ is excreted (Boisen et al. 2000). Optimized protein feeding should therefore be based on the concept of ideal protein and digestible amino acid content of the feed, since only digestible amino acids are at the animal's disposal. In low-protein feeding, balanced amino acid composition is especially important as the excessive protein and therefore amino acids are limited. However, research in the amino acid requirements or the amino acid digestibility of blue fox is scarce and amino acid recommendations for blue fox are lacking (Lassén et al. 2012). 
Currently, only one study has been conducted on the optimum amino acid pattern in 9-week-old blue fox cubs (Dahlman et al. 2004). According to the effect on $\mathrm{N}$ retention and growth, Dahlman et al. (2004) showed that the first three limiting essential amino acids are methionine (MET) + cystine (CYS), threonine and histidine (HIS). Sulphur-containing amino acids (SAA), MET and CYS, are known to have crucial role in fur animal diets, since $49 \%$ of hair protein is SAA, for the most part CYS (Glem-Hansen 1980, Glem-Hansen and Hansen 1981). The effects of supplemented MET, as an essential amino acid and precursor for CYS, have been studied in blue fox and found to positively affect growth (Dahlman et al. 2003), digestibility (Dahlman et al. 2002a, Gugolek et al. 2017) and pelt quality (Dahlman et al. 2003, Gugolek et al. 2012).

Based on these previous studies, we presupposed that MET supplementation would be essential in low protein diets and, in addition, we determined the effect of HIS supplementation on performance in blue fox. Dahlman (2003) used feed treatments resembling those in our study, but feeding was prolonged to cover the growing period from mid-August to pelting. In our study, we divided the growing-furring period into two section, because Dahlman's studies (2003) showed that the protein requirement decreases as blue foxes reach maturity. We hypothesized that the protein requirements of blue fox may be higher early in the period (trial 1) than in the latter part (trial 2).

The objectives here were to determine the effects of low dietary protein with or without DL-methionine and L-histidine supplementation on growth, pelt size and pelt quality in blue fox in the two periods of the growing-furring season. Optimized protein feeding based on the amino acid ratio of the protein and optimized throughout growing-furring season, is likely to benefit production profitability and decrease the environmental effects of the production.

\section{Materials and methods}

\section{Experimental diets and feeding}

In both trials, three dietary protein levels, with or without MET and HIS supplementation were studied. In trial 1 , the diets were P24, P20, P20M, P16M and P16MH. The control diet (P24) contained DCP at levels (DCP) 24\% of ME with no amino acid supplements. The experimental diets contained DCP al levels $20 \%$ of ME with and without MET supplementation (P20 and P2OM) and $16 \%$ of ME with MET and with MET and HIS supplements (P16M and $\mathrm{P} 16 \mathrm{MH}$ ). MET and HIS supplementation was calculated to bring the amino acid in question up to a level similar to that in the control group. The composition of the diets is presented in the Table 1.

Table 1. Composition of experimental diets $\left(\mathrm{g} \mathrm{kg}^{-1}\right)$ in trial 1

\begin{tabular}{|c|c|c|c|c|c|}
\hline & $\mathrm{P} 24$ & $\mathrm{P} 20$ & P20M & P16M & $\mathrm{P} 16 \mathrm{MH}$ \\
\hline Slaughter by-products, pork & 30 & 25 & 25 & 19 & 19 \\
\hline Slaughter by-products, poultry & 260 & 213 & 213 & 165 & 165 \\
\hline Precooked barley & 170 & 139 & 139 & 107 & 107 \\
\hline Fish meal & 36 & 29 & 29 & 23 & 23 \\
\hline Treacle-sugarbeet pulp & 20 & 25 & 25 & 26 & 26 \\
\hline Wheat bran & 20 & 25 & 25 & 26 & 26 \\
\hline DL-Methionine & & & 0.8 & 1.3 & 1.3 \\
\hline L-Histidine & & & & & 0.9 \\
\hline Water & 215 & 275 & 274 & 359 & 358 \\
\hline
\end{tabular}

P24 = DCP $24 \%$ of ME; P20 = DCP $20 \%$ of ME; P20M = DCP $20 \%$ of ME + MET; P16M = DCP 16\% of ME + MET; P16MH = DCP $16 \%$ of ME + MET + HIS; DM = dry matter; $M E$ = metabolisable energy; $D C P$ = digestible crude protein; $M E T=$ methionine; HIS = histidine 
In trial 2, the diets were P20, P16.5, P16.5M, P13M and P13MH. The control diet (P20) contained DCP at levels 20 $\%$ of ME. The experimental diet contained DCP $16.5 \%$ of ME with and without MET (P16.5 and P16.5M) and 13 $\%$ of ME with MET and with or without HIS (P13M and P13MH). MET and HIS supplementation brought the amino acid in question up to the level similar to that in the control group. The composition of the diets is presented in the Table 2.

\begin{tabular}{lccccc} 
Table 2. Composition of experimental diets $\left(\mathrm{g} \mathrm{kg}^{-1}\right)$ in trial 2 & \multicolumn{5}{l}{} \\
\hline & $\mathrm{P} 20$ & $\mathrm{P} 16.5$ & $\mathrm{P} 16.5 \mathrm{M}$ & $\mathrm{P} 13 \mathrm{M}$ & $\mathrm{P} 13 \mathrm{MH}$ \\
\hline Baltic herring, autumn & 210 & 166 & 166 & 124 & 124 \\
Slaughter by-products, poultry & 160 & 126 & 126 & 97 & 97 \\
Precooked barley & 190 & 150 & 150 & 113 & 113 \\
Feather meal, hydrolysed & 40 & 33 & 33 & 24 & 24 \\
Treacle-sugarbeet pulp & 30 & 30 & 30 & 30 & 30 \\
Wheat bran & 30 & 30 & 30 & 30 & 30 \\
Lard & 76 & 82.5 & 82.5 & 95 & 95 \\
Mineral mixture & 2.0 & 2.0 & 2.0 & 2.0 & 2.0 \\
Cooked wheat starch & & 45 & 45 & 72 & 72 \\
DL-Methionine & 2.2 & 1.9 & 2.6 & 2.9 & 2.9 \\
L-Histidine & & & & & 0.7 \\
Water & 260 & 334 & 333 & 410 & 409 \\
\hline
\end{tabular}

P20 = DCP $20 \%$ of ME; P16.5 = DCP 16.5\% of ME; P16.5M = DCP 16.5\% of ME + MET; P13M = DCP 13\% of ME + MET; P13MH = DCP $13 \%$ of $\mathrm{ME}+\mathrm{MET}+\mathrm{HIS} ; \mathrm{DM}=$ dry matter; $\mathrm{ME}=$ metabolisable energy; $\mathrm{DCP}=$ digestible crude protein; $\mathrm{MET}=$ methionine; $\mathrm{HIS}=$ histidine

In both trials, wheat starch was added to lower the amount of protein. The crude fat content was designed to be constant throughout the diets. The calculated levels of crude protein, MET and HIS are presented in Tables 1 and 2. In trial 1 , the daily feeding ratio was on an as-fresh basis of $1000 \mathrm{~g}$ per animal, fed once per day. In trial 2 , the daily feeding ratio was on an as-fresh basis of $900 \mathrm{~g}$ per animal, fed once per day. Drinking water was freely available in both trials.

\section{Animals and study design}

The trials were conducted at the Kannus Research Farm Luova Ltd, Kannus, Finland. Trial 1 was conducted 3 October-2 November 2016 with 200 blue foxes and trial 2 November 10-15 December 2016 with 200 blue foxes. The animals were housed as male-female pairs in conventional cages, semi-outdoors in two-row sheds. The experimental design was a completely random trial, with 20 replicates for each diet, since the unit used in the growth analysis was the cage. The unit used in the analysis of pelt characteristics was individual animal and therefore the replicates for each diet were 40 .

In trial 1, the age of the animals was on average 20 weeks at the beginning of the experiment. The initial body weight of the animals was on average ( \pm standard deviation SD) $12.2 \pm 1.1 \mathrm{~kg}$. The animals were fed the experimental diets for 30 days. Before and after the experimental period, the animals were fed a basic farm diet until pelting (8-9 December 2016). In trial 2, the age of the animals was on average 25 weeks at the beginning of the experiment. The initial body weight of the animals was on average $( \pm$ SD) $17.4 \pm 2.1 \mathrm{~kg}$. The animals were fed the experimental diets for 35 days until pelting (15 December 2016). Before the experimental period, the animals were fed a basic farm diet.

\section{Growth, pelt quality and pelt size}

Feed consumption was observed daily. In the trial 1, the ADG was measured by weighing the animals 4 times (3.10., 21.10, 2.11. and 15.12.) and in the trial 2, 3 times (10.11., 29.11. and 15.12.). The body length of the animals from nose-tip to tail-root was measured immediately after they were killed by electrocution. 
Pelt quality was graded by Fox Craft Ltd, Uusikaarlepyy, Finland on a scale was determined of 0 (Saga II = poorest), 1 (Saga I), 2 (Saga), 4 (Saga Royal = best). The pelt size was measured by Fox Craft as pelt size categories, which were then converted into average centimetres. Pelt length for size categories was $70=>151 \mathrm{~cm}, 60=142-151 \mathrm{~cm}$, $50=133-142 \mathrm{~cm}, 40=124-133 \mathrm{~cm}, 30=<124 \mathrm{~cm}$.

\section{Chemical analysis and calculations}

The feed samples were collected at the beginning of the trial. The chemical composition of the feed was analysed by standard methods in the Laboratory of Fin Furlab Ltd., Vaasa, Finland. Moisture and ash were determined by the Nordic Committee on Food Analysis (NMKL) method 23 (NMKL 1991) gravimetric determination, crude protein by NMKL method 6 (NMKL 2003) according to Kjeldahl and crude fat by soxhlet extraction after acid hydrolysis (AOAC 1995). The crude carbohydrates were then calculated as the difference obtained by subtracting ash, crude protein and crude fat from the dry matter (DM) content. The feed amino acids were determined by ultra performance liquid chromatography (UPLC) method as described in Puhakka et al. (2016) in the Laboratory of Agricultural Sciences, University of Helsinki, Finland. The ME MJ kg-1 content of the feeds was calculated using chemical composition, digestibility coefficients carried out with the feed in question (Ylinen et al. unpublished data) and $\mathrm{ME}\left(\mathrm{MJ} \mathrm{kg}^{-1}\right.$ ) values: protein $(\mathrm{N} \times 6.25)$ 18.8; fat 39.8; carbohydrates 17.6 (Hansen et al. 1991). The energy distribution was calculated according to Hansen et al. (1991).

\section{Statistical analysis}

Statistical analysis of growth and body length data was performed with the general linear model (GLM) procedure of SAS 9.4 (SAS Institute, Cary, NC, USA). The data was determined to be normally distributed using the Shapiro-Wilk test. The model used in the analysis of growth and body length was:

$$
Y_{i j}=\mu+d_{i}+\varepsilon_{i j}
$$

where $Y_{i j}=$ the observation, $\mu=$ the general mean, $d_{i}=$ the effect of diet $(I=1, \ldots, 5)$ and $\varepsilon_{i j}=$ a random effect. The diet effect was tested using four orthogonal contrasts: $\mathrm{C} 1$ tested the effect of the control diet against the experimental diets. C2 tested the effect of the protein level between groups P20 and P16 (trial 1) or between groups P16.5 and P13 (trial 2). C3 tested the effect of MET supplementation between groups P20 and P20M (trial 1) or between groups P16.5 and P16.5M (trial 2). C4 tested the effect of HIS supplementation between groups P16M and P16MH (trial 1) or between groups P13M and P13MH (trial 2). Statistical analysis of the pelt size and pelt quality was performed with the nonparametric Kruskal-Wallis test of SAS 9.4 in both trials.

\section{Results}

\section{Chemical composition of the diets and feed consumption}

The experimental diets followed the levels designed with some differences. In trial 1, DM content was highest in the control diet (Table 3). The DCP as percentage of the ME was lower than designed. The DCP content was on average $21 \%, 18 \%$, and $14 \%$ of $\mathrm{ME}$ in diets P24, P20 and P16, respectively. The fat $\left(\mathrm{g} \mathrm{kg}^{-1} \mathrm{DM}\right.$ ) and energy (ME MJ $\mathrm{kg}^{-1} \mathrm{DM}$ ) contents were higher than planned in the P16 groups. The amino acid content $\left(\mathrm{g} \mathrm{kg}^{-1} \mathrm{DM}\right)$ is presented in Table 4. In trial 1, the MET content in MET supplemented groups P16M and P16MH exceeded the methionine content of control group. The lowest content was in the diet not supplemented with MET (P20), as planned. In contrast, the supplemented HIS in the group P16MH did not reach the level of the control group, as planned.

Feed consumption was on a DM basis averaged 396, 370 and $369 \mathrm{~g}$ per day per animal in groups P24, P20 and P16, respectively (Table 3). No feed residues were detected. The ME intake was highest in the control group. MET intake was lowest in the experimental group without MET-supplementation (P20) and exceeded the intake of the control group in all groups with supplemented MET. HIS intake in HIS supplemented group did not reach the level of HIS intake of the control group, and exceeded only slightly the HIS intake in the group P16M. 
Table 3. Chemical composition of the diets and daily intake of DM, (g), ME (MJ), MET and HIS (g) in trial 1

\begin{tabular}{|c|c|c|c|c|c|}
\hline & P24 & P20 & P2OM & P16M & P16MH \\
\hline \multirow[t]{2}{*}{$\mathrm{DM}\left(\mathrm{g} \mathrm{kg}^{-1}\right)$} & 396 & 367 & 373 & 366 & 371 \\
\hline & \multicolumn{5}{|c|}{ In dry matter ( $\left.\mathrm{g} \mathrm{kg}^{-1} \mathrm{DM}\right)$} \\
\hline Protein & 279 & 253 & 238 & 219 & 216 \\
\hline Fat & 280 & 278 & 263 & 304 & 297 \\
\hline Carbohydrates & 371 & 400 & 440 & 428 & 434 \\
\hline Ash & 70 & 69 & 59 & 50 & 53 \\
\hline \multirow[t]{2}{*}{$\mathrm{ME}\left(\mathrm{MJ} \mathrm{kg}{ }^{-1} \mathrm{DM}\right)$} & 19.2 & 18.9 & 18.7 & 20.2 & 20.0 \\
\hline & \multicolumn{5}{|c|}{ Energy distribution } \\
\hline Protein & 20.7 & 18.5 & 17.0 & 14.7 & 13.6 \\
\hline Fat & 54.9 & 56.0 & 53.9 & 57.5 & 56.1 \\
\hline Carbohydrates & 24.4 & 25.5 & 29.2 & 27.8 & 30.4 \\
\hline \multirow[t]{2}{*}{$\mathrm{F}: \mathrm{C}$} & 2.3 & 2.2 & 1.8 & 2.1 & 1.8 \\
\hline & \multicolumn{5}{|c|}{ Daily intake } \\
\hline DM & 396 & 367 & 373 & 366 & 371 \\
\hline ME & 7.59 & 6.95 & 6.96 & 7.39 & 7.42 \\
\hline MET & 2.0 & 1.5 & 2.3 & 2.6 & 2.6 \\
\hline HIS & 2.2 & 1.7 & 1.6 & 1.7 & 1.8 \\
\hline
\end{tabular}

Table 4. Amino acid composition of the diets $\left(\mathrm{g} \mathrm{kg}^{-1} \mathrm{DM}\right)$ in trial 1

\begin{tabular}{|c|c|c|c|c|c|}
\hline & P24 & P20 & P20M & P16M & $\mathrm{P} 16 \mathrm{MH}$ \\
\hline Arginine & 16.9 & 14.6 & 15.1 & 14.2 & 12.6 \\
\hline Cystine & 3.8 & 2.7 & 3.3 & 3.6 & 2.7 \\
\hline Histidine & 6.3 & 5.2 & 5.3 & 5.2 & 5.6 \\
\hline Isoleucine & 10.2 & 9.5 & 9.8 & 9.0 & 8.2 \\
\hline Leucine & 20.6 & 17.8 & 18.0 & 17.4 & 15.1 \\
\hline Lysine & 15.3 & 14.2 & 14.1 & 14.0 & 11.8 \\
\hline Methionine & 5.1 & 4.0 & 6.4 & 7.1 & 6.9 \\
\hline Phenylalanine & 11.9 & 10.0 & 10.3 & 9.7 & 8.7 \\
\hline Threonine & 10.8 & 9.7 & 9.8 & 9.4 & 8.3 \\
\hline Tryptophan & 1.9 & 1.7 & 1.7 & 1.5 & 1.5 \\
\hline Valine & 14.7 & 12.8 & 12.9 & 12.5 & 10.8 \\
\hline$\Sigma$ Total $^{1}$ & 253 & 221 & 227 & 219 & 192 \\
\hline
\end{tabular}

${ }^{1}$ Includes the essential amino acids listed in the table and the non-essential amino acids alanine, aspartic acid, glutamic acid, glycine, proline, serine, tyrosine; P24 = DCP 24\% of ME; P20 = DCP $20 \%$ of ME; P20M = DCP $20 \%$ of ME + MET; P16M = DCP $16 \%$ of ME + MET; P16MH = DCP $16 \%$ of ME + MET + HIS; DM = dry matter; ME = metabolisable energy; DCP = digestible crude protein; $\mathrm{MET}=$ methionine; $\mathrm{HIS}=$ histidine

In trial 2, the control feed showed the lowest DM content (Table 5). The protein level of the diets was higher than designed. The DCP content was on average $21 \%, 18 \%, 16 \%$ of ME in the diets P20, P16.5 and P13, respectively. The fat content as $\mathrm{g} \mathrm{kg}^{-1} \mathrm{DM}$ was the highest in control diet but energy (ME MJ kg-1 DM) content was constant between diets. The amino acid content ( $\mathrm{g} \mathrm{kg}^{-1} \mathrm{DM}$ ) is presented in Table 6 . In trial 2, MET level was higher than planned. MET content was lowest in the treatment group without MET-supplementation, as planned. HIS content in HIS supplemented group did not quite reach the level of the control group but exceeded the treatment groups without HIS supplementation. 
Feed consumption was on a DM basis averaged 375,400 and $397 \mathrm{~g}$ per day in groups P20, P16.5 and P13, respectively (Table 5). DM level was high (417-449 $\mathrm{g} \mathrm{kg}^{-1} \mathrm{DM}$ ) and the texture was not optimal for feeding practices. However, only minor feed residues were observed and the amount was not measured. The ME intake was lowest in the control group and increased when the protein content decreased. The MET intake was only slightly lower in experimental group without MET supplementation (P16.5) and exceeded the intake of the control group in all groups with supplemented MET. The HIS intake followed the design, since it was lowest in the low-protein groups without HIS supplementation and reached the control diet level in the HIS supplemented group.

In both trials, the content of carbohydrates (percentage of $\mathrm{ME}$ ) increased when the protein content decreased, due to the increasing portion of wheat starch (Tables 3 and 5). The fat:carbohydrates (F:C) ratio decreased as the content of carbohydrates increased.

Table 5. Chemical composition of the diets and daily intake of DM, (g), ME (MJ), MET and HIS (g) in trial 2

\begin{tabular}{|c|c|c|c|c|c|}
\hline & $\mathrm{P} 20$ & P16.5 & P16.5M & P13M & $\mathrm{P} 13 \mathrm{MH}$ \\
\hline \multirow[t]{2}{*}{$\mathrm{DM}\left(\mathrm{g} \mathrm{kg}^{-1}\right)$} & 417 & 449 & 440 & 438 & 445 \\
\hline & \multicolumn{5}{|c|}{ In dry matter ( $\left.\mathrm{g} \mathrm{kg}^{-1} \mathrm{DM}\right)$} \\
\hline Protein & 276 & 236 & 225 & 212 & 216 \\
\hline Fat & 242 & 228 & 237 & 233 & 228 \\
\hline Carbohydrates & 414 & 478 & 480 & 499 & 501 \\
\hline Ash & 68 & 58 & 58 & 56 & 55 \\
\hline \multirow[t]{2}{*}{$\mathrm{ME}\left(\mathrm{MJ} \mathrm{kg}^{-1}\right)$} & 18.2 & 17.7 & 18.0 & 18.3 & 18.3 \\
\hline & \multicolumn{5}{|c|}{ Energy distribution } \\
\hline Protein & 21.1 & 17.8 & 17.4 & 15.9 & 15.6 \\
\hline Fat & 50.1 & 49.5 & 49.8 & 48.5 & 46.5 \\
\hline Carbohydrates & 28.8 & 32.8 & 32.7 & 35.6 & 37.9 \\
\hline \multirow[t]{2}{*}{$\mathrm{F}: \mathrm{C}$} & 1.7 & 1.5 & 1.5 & 1.4 & 1.2 \\
\hline & \multicolumn{5}{|c|}{ Daily intake } \\
\hline DM & 375 & 404 & 396 & 394 & 401 \\
\hline ME & 6.84 & 7.16 & 7.11 & 7.21 & 7.33 \\
\hline MET & 3.0 & 2.8 & 3.3 & 3.1 & 3.3 \\
\hline HIS & 1.8 & 1.5 & 1.4 & 1.3 & 1.7 \\
\hline
\end{tabular}

Energy distribution as percentage of ME. F:C = fat:carbohydrates ratio; P20 = DCP 20\% of ME; P16.5 = DCP 16.5\% of ME; P16.5M = DCP $16.5 \%$ of ME + MET; P13M = DCP 13\% of ME + MET; P13MH = DCP 13\% of ME + MET + HIS; DM = dry matter; ME = metabolisable energy; $\mathrm{DCP}=$ digestible crude protein; $\mathrm{MET}=$ methionine; $\mathrm{HIS}=$ histidine

Table 6. Amino acid composition of the diets $\left(\mathrm{g} \mathrm{kg}^{-1} \mathrm{DM}\right)$ in trial 2

\begin{tabular}{|c|c|c|c|c|c|}
\hline & P20 & P16.5 & P16.5M & P13M & $\mathrm{P} 13 \mathrm{MH}$ \\
\hline Arginine & 18.5 & 15.6 & 14.4 & 14.4 & 13.5 \\
\hline Cystine & 5.2 & 6.1 & 6.0 & 4.9 & 4.6 \\
\hline Histidine & 5.6 & 4.2 & 3.9 & 3.8 & 4.9 \\
\hline Isoleucine & 11.7 & 10.3 & 9.8 & 9.7 & 9.0 \\
\hline Leucine & 22.1 & 18.6 & 17.5 & 17.3 & 16.5 \\
\hline Lysine & 13.1 & 9.3 & 9.4 & 9.1 & 9.3 \\
\hline Methionine & 7.8 & 6.7 & 8.1 & 7.8 & 8.1 \\
\hline Phenylalanine & 13.1 & 11.3 & 10.3 & 10.3 & 10.0 \\
\hline Threonine & 12.0 & 10.2 & 9.7 & 9.6 & 9.0 \\
\hline Tryptophan & 2.1 & 1.5 & 1.6 & 1.7 & 1.6 \\
\hline Valine & 16.9 & 14.8 & 13.9 & 13.8 & 13.0 \\
\hline$\Sigma$ Total $^{1}$ & 276 & 232 & 222 & 218 & 211 \\
\hline
\end{tabular}

${ }^{1}$ Includes the essential amino acids listed in the table and the non-essential amino acids alanine, aspartic acid, glutamic acid, glycine, proline, serine, tyrosine; P20 = DCP 20\% of ME; P16.5 = DCP 16.5\% of ME; P16.5M = DCP 16.5\% of ME + MET; P13M = DCP $13 \%$ of ME + MET; P13MH = DCP $13 \%$ of ME + MET + HIS; DM = dry matter; $\mathrm{ME}=$ metabolisable energy; $\mathrm{DCP}=$ digestible crude protein, $\mathrm{MET}=$ methionine; HIS = histidine 


\section{Performance in trial 1}

In trial 1, the feeds were generally eaten well and the animals were healthy with normal faecal consistency. Three animals were culled during the trial due to infection not related to the experiment. Their cages and five outliers were excluded ( $n=8$ cages) from the growth analysis. Pelt quality and pelt size were analysed for 187 individuals, because 10 ( 2 males, 8 females) pelt identification tags became loosened.

Blue foxes fed the control diet (P24) showed greater ADG than with other diets $(p<0.0001$, Table 7). The effect was not linear, since groups P16 showed greater ADG than did groups P20 ( $p=0.0009)$. The effect of greater ADG in the control group and in groups P16 tapered off when the first 18 days were compared to the last 12 days of the experimental period ( $p<0.0001$ vs. $p=0.93$ and $p<0.0001$ vs. $p=0.74$, respectively). The final body weight of the animals was the highest $(p=0.02)$ in the control group. The MET and HIS supplementation had no effect on ADG, but the MET-supplementation did positively affect the body length in males $(p=0.01)$ and in females $(p=0.05)$.

The pelt quality or pelt size did not differ between groups (Table 7). In males, the best quality was achieved in the control group and in females in the lowest protein group, but the effect was not statistically significant.

Table 7. Performance results in trial 1

\begin{tabular}{|c|c|c|c|c|c|c|c|c|c|c|c|}
\hline & P24 & P20 & P20M & P16M & P16MH & SEM $^{1}$ & $\mathrm{C} 1$ & $\mathrm{C} 2$ & C3 & $\mathrm{C} 4$ & K-W \\
\hline \multicolumn{12}{|c|}{ ADG (g) } \\
\hline Whole period & 108 & 89.9 & 89.7 & 94.1 & 96.9 & 1.726 & $* * *$ & $* * *$ & ns & ns & \\
\hline First 18 days & 129 & 97.4 & 98.3 & 105 & 108 & 2.220 & $* * *$ & $* * *$ & ns & ns & \\
\hline Last 12 days & 77.9 & 78.5 & 76.9 & 77.4 & 80.2 & 3.421 & ns & ns & ns & ns & \\
\hline \multirow[t]{2}{*}{ Final BW (kg) } & 18.33 & 18.00 & 17.59 & 18.01 & 17.52 & 0.186 & $*$ & ns & ns & ns & \\
\hline & \multicolumn{11}{|c|}{ Males } \\
\hline Body length $(\mathrm{cm})$ & 76.9 & 74.8 & 76.8 & 76.0 & 75.8 & 0.538 & ns & ns & $*$ & ns & \\
\hline Pelt quality (1-4) & 2.11 & 1.79 & 1.84 & 1.61 & 1.90 & 0.122 & & & & & ns \\
\hline \multirow[t]{2}{*}{ Pelt size $(\mathrm{cm})$} & 143 & 140 & 143 & 144 & 142 & 1.651 & & & & & ns \\
\hline & \multicolumn{11}{|c|}{ Females } \\
\hline Body length $(\mathrm{cm})$ & 72.5 & 71.6 & 72.9 & 72.1 & 72.2 & 0.469 & ns & ns & $*$ & ns & \\
\hline Pelt quality (1-4) & 1.84 & 1.78 & 1.68 & 1.68 & 1.94 & 0.161 & & & & & ns \\
\hline Pelt size $(\mathrm{cm})$ & 134 & 135 & 134 & 133 & 133 & 1.490 & & & & & ns \\
\hline \multicolumn{12}{|c|}{ 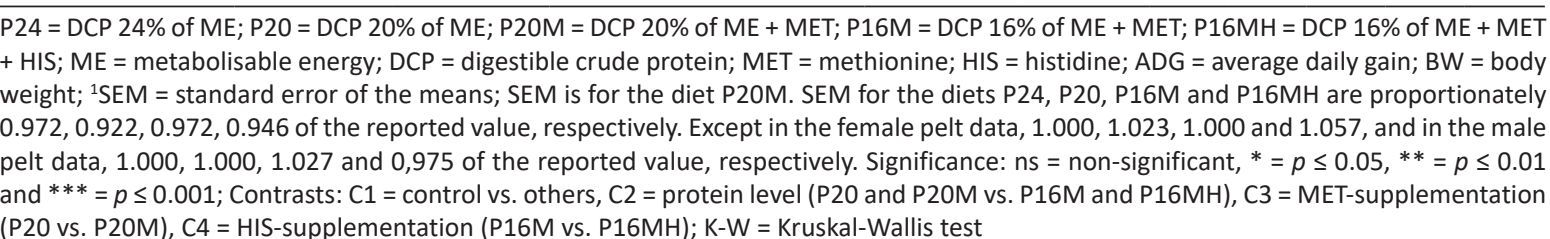 } \\
\hline
\end{tabular}

\section{Performance in trial 2}

In trial 2, the feeds were generally eaten well and the animals were healthy with normal faecal consistency. Three animals were culled during the trial, due to infection not related to the experiment. Their cages $(n=3$ cages) were removed from growth analysis. Pelt quality and pelt size were analysed with 193 individuals, because four ( 3 males, 1 female) pelt identification tags became loosened.

Blue foxes fed the control diet showed the lowest ADG $(p=0.002)$, while group P16.5M showed the highest ADG (Table 8). The total weight gain in all groups was relatively slow and the animals gained weight mainly in the first 19 days of the experimental period compared with the last 16 days. The final body weight of the animals was the lowest $(p=0.008)$ in the control group. The MET-supplementation tended to increase the ADG $(p=0.06)$, HIS-supplementation did not affect the ADG. The body length did not differ between groups, albeit males tended to have longer body length in the control group $(p=0.06)$. 
The pelt quality did not differ between groups (Table 8). In males, the best pelt quality was achieved in groups P13 and in females, in the group P13M, but the effect was not statistically significant.

Table 8. Performance results in trial 2

\begin{tabular}{|c|c|c|c|c|c|c|c|c|c|c|c|}
\hline & P20 & P16.5 & $\mathrm{P} 16.5 \mathrm{M}$ & P13M & $\mathrm{P} 13 \mathrm{MH}$ & $\mathrm{SEM}^{1}$ & $\mathrm{C} 1$ & $\mathrm{C} 2$ & $\mathrm{C} 3$ & $\mathrm{C} 4$ & K-W \\
\hline & \multicolumn{11}{|c|}{ ADG (g) } \\
\hline Whole period & 41.5 & 48.1 & 55.8 & 50.7 & 49.6 & 2.833 & $* *$ & ns & $\bigcirc$ & ns & \\
\hline First 19 days & 73.3 & 74.1 & 93.8 & 88.9 & 94.6 & 7.539 & $\bigcirc$ & ns & $\bigcirc$ & ns & \\
\hline Last 16 days & 3.70 & 17.3 & 10.6 & 5.20 & -3.90 & 7.221 & ns & $\bigcirc$ & ns & ns & \\
\hline \multirow[t]{2}{*}{ Final BW (kg) } & 18.58 & 18.90 & 19.56 & 19.30 & 19.65 & 0.252 & $* *$ & ns & ns & ns & \\
\hline & \multicolumn{11}{|c|}{ Males } \\
\hline Body length (cm) & 79.5 & 77.2 & 78.6 & 79.4 & 78.0 & 0.616 & $\bigcirc$ & ns & ns & ns & \\
\hline Pelt quality (1-4) & 2.05 & 1.63 & 1.68 & 2.11 & 2.10 & 0.177 & & & & & ns \\
\hline \multirow[t]{2}{*}{ Pelt size $(\mathrm{cm})$} & 145 & 144 & 142 & 146 & 147 & 1.585 & & & & & ns \\
\hline & \multicolumn{11}{|c|}{ Females } \\
\hline Body length (cm) & 73.9 & 74.3 & 73.9 & 74.0 & 74.5 & 0.460 & ns & ns & ns & ns & \\
\hline Pelt quality (1-4) & 1.74 & 1.75 & 1.74 & 1.80 & 1.56 & 0.146 & & & & & ns \\
\hline Pelt size $(\mathrm{cm})$ & 133 & 135 & 138 & 137 & 140 & 1.513 & & & & & ns \\
\hline
\end{tabular}

P20 = DCP $20 \%$ of ME; P16.5 = DCP 16.5\% of ME; P16.5M = DCP 16.5\% of ME + MET; P13M = DCP 13\% of ME + MET; P13MH = DCP 13\% of $\mathrm{ME}+\mathrm{MET}+\mathrm{HIS} ; \mathrm{ME}$ = metabolisable energy; $\mathrm{DCP}=$ digestible crude protein; $\mathrm{MET}=$ methionine; $\mathrm{HIS}=$ histidine; $\mathrm{ADG}=$ average daily gain; $\mathrm{BW}=$ body weight; ${ }^{1} \mathrm{SEM}=$ standard error of the means. SEM is for the diet P16.5. SEM for the diets P20, P16.5M, P13M and P13MH are proportionately $0.922,0,946,0,972,0.972$ of the reported value, respectively. Except in the female pelt data, 1.026, 1.026, 1.000 and 1.054, and in the male pelt data, $0.894,0.918,0.918$ and 0.894 of the reported value, respectively. Significance: $\mathrm{ns}=$ non-significant, $\bigcirc=p<0.10$, $*=p \leq 0.05, * *=p \leq 0.01$ and $* * *=p \leq 0.001$; Contrasts: $\mathrm{C} 1=$ control vs. others, $\mathrm{C} 2=$ protein level (P16.5 and P16.M vs. $\mathrm{P} 13 \mathrm{M}$ and $13 \mathrm{MH})$, $\mathrm{C} 3=$ MET-supplementation (P16.5 vs. P16.5M), C4= HIS-supplementation (P13M vs. P13MH); K-W = Kruskal-Wallis test

\section{Discussion}

In trial 1, the total crude protein content $\left(\mathrm{g} \mathrm{kg}^{-1} \mathrm{DM}\right)$ of the diets followed the levels designed. The protein level as percentage of ME was lower than designed, likely due to the low protein digestibility coefficient from the digestibility trial carried out with this feed (Ylinen et al. unpublished data). In trial 2, the total crude protein level ( $\mathrm{g} \mathrm{kg}^{-1}$ DM) of the diets was higher than designed, but decreased linearly. These inaccuracies in feed formulation resulted in differences between the designed and actual protein contents of the diets. MET and HIS supplementation in the supplemented groups did increase MET and HIS content of the diets and daily intake of these amino acids up to the level of the control group, with the exception of HIS supplementation in trial 1, where HIS content did not reached the level of the control group. In trial 2, MET and HIS content was abundant also in the not-supplemented group.

In our study, weight gain was faster in control diet when the blue foxes were 20 weeks of age. The effect diminished during trial 1, while in trial 2 the higher dietary protein did not positively affect growth. The effect was similar when looking at the final body weights. In the trial 1, animals in the control group had the highest final body weight and in the trial 2, the lowest final body weight. In both trials, the animals were fed on an as-fresh basis. Since the DM content of the feeds varied, it resulted in variation in DM intake between the groups. Fur animal feeds are rich in energy and small differences in DM intake may result in higher ME intake and therefore faster weight gain. In trial 1, the DM intake was greatest and, correspondingly, ADG was fastest in control group. The average daily ME intake in the control group was $0.64 \mathrm{MJ}$ more than in groups P20. This does not totally cover the MJ needed for additional ADG, because the energy cost needed to cover the additional ADG between the control group and groups P20 would then be 0.95 MJ ME per day (calculated after Pullar \& Webster (1977) using an energy cost $53 \mathrm{~kJ} \mathrm{~g}^{-1}$ for fat or protein deposition). However, the growth results in our study were non-linear, since growth did not decrease linearly with decreasing protein level. Instead, the growth results followed the ME intake, since groups P16 showed faster ADG than groups P20 and greater ME intake (0.45 MJ daily). Therefore, the $\mathrm{ME}$ intake along with the protein level likely resulted in growth of the animals. In trial 2, the ME intake was more similar between diets (daily intake 6.2-6.4 MJ ME). Still, DM intake was lowest and, correspondingly, weight gain slowest in the control group. In addition, ADG and ME intake increased at equal linear rates. 
Our results are in line with Dahlman et al. (2002a, 2002b, 2003), who found that weight gain of 11-16 weeks old blue foxes was positively affected when dietary protein level was $22.5-30 \%$ of ME compared with $15 \%$ of ME, but also that $15 \%$ of ME from protein was sufficient for blue foxes that have reached full maturity. They concluded that the requirement for dietary protein over $15 \%$ of ME diminishes after muscular and skeletal growth is over at about 14 weeks of age in blue foxes. In our study, the blue foxes were 20 weeks of age at the beginning of the trial 1. When the advantage in ADG in the control group diminished in the middle of trial 1, the animals were on average 22 weeks-of-age. Blue fox at that age have reached full maturity and growth is manifested mainly as the accumulation of fat (Dahlman et al. 2003). At the beginning of trial 2 in November, the animals were 25 weeks of age and no advantage of dietary protein over $15 \%$ of ME was shown. Conversely, the weight gain was positively affected by the decreasing protein level. The effect may have been due to the higher DM intake and, therefore, higher ME intake of animals in the low-protein groups.

In our study, the experimental diets (protein level or supplemented MET and HIS) resulted in no negative effects on pelt quality or pelt size, indicating that the protein and amino acid supplies were sufficient. However, our experimental periods were 30 days and 35 days in trials 1 and 2, respectively. This is likely to be too short a period to reveal any clear effects on pelt characteristic between diets. In addition, the animals in trial 1 were fed a basic farm diet for 36 days after the experimental period until pelting. This 5-week period between experimental feeding and pelting could have influenced the pelting results in the trial 1 and these results must therefore be interpreted with caution. In trial 2, the blue foxes were 25 weeks of age, when the peak in developing winter hair has usually passed (Dahlman et al. 2002a). However, histological studies of the pelage cycle in blue fox have shown that pelage maturation is not completed even in December, when the animals are on average $26-27$ weeks of age (Blomstedt 1998). Still, the majority of the guard hairs and under hairs are mature at that time and the protein demand is low (Blomstedt 1998, Dahlman et al. 2003). In the context of protein and amino acid intake, it is known that lower dietary protein contents result in reduced hair properties (Rasmussen and Børsting 2000) and more generally on pelt quality in mink (Työppönen et al. 1986, Sandbøl et al. 2004) and in blue fox (Dahlman et al. 2003). In their study in mink, Rasmussen and Børsting (2000) concluded that low-protein diets in late growing-furring season (22 week of age until pelting) reduce hair growth, regardless of previous protein supply.

In trial 1, MET content was lowest at $4.0 \mathrm{~g} \mathrm{~kg}^{-1} \mathrm{DM}$ and when supplemented at $6.4-7.1 \mathrm{~g} \mathrm{~kg}^{-1} \mathrm{DM}$. In the studies of Dahlman et al. (2002a, 2003), MET content was lowest at $4.1 \mathrm{~g} \mathrm{~kg}^{-1} \mathrm{DM}$ and when supplemented at 8.3-9.5 g kg-1 DM. The authors found that the MET supplementation positively affected growth when the blue foxes were 1116 weeks of age and pelt quality when blue foxes were over 16 weeks of age until pelting. In our study, MET supply was lower than in Dahlman's studies. The requirement for MET in blue fox have considered to be pronounced in the late growing-furring phase due the developing winter fur (Dahlman et al. 2003). Our 30-days experimental period may have been too short to reveal any clear benefit of supplemented MET, since Dahlman's experiments (2003) continued over 100 days from mid-August until pelting. However, all examined blue foxes in their study received same experimental diets from mid-August until pelting and it is therefore impossible to distinguish the effect of the diets fed early (August-September) or late (October-November) in the growing-furring period. In addition, Glem-Hansen $(1980,1982)$ has shown in mink that mink's MET requirements decrease during the late growing-furring period. Considering the above-mentioned, it cannot be excluded that the MET content in the diets in our trial 1 was sufficient, as the requirement for MET may be reduced in the later growing-furring season (October-November) comparing to the earlier phase of the season. In trial 2, the MET supply was greater than in trial 1 and resembled more that in Dahlman's studies (2002a, 2003). In the diet not supplemented with MET (P16.5), MET content was also abundant (6.7 $\left.\mathrm{g} \mathrm{kg}^{-1} \mathrm{DM}\right)$ and we concluded that methionine supply was sufficient in all the diets in trial 2. In blue fox, decreasing requirement for MET during the late growing-furring season has not been demonstrated as in mink (Glem-Hansen 1980, 1982), but our results indicate that the MET requirement in the late growing-furring period in blue fox may not be as pronounced than has been previously thought (Dahlman et al. 2003). However, MET intake may have been too similar to reveal any differences between diets.

HIS was the third limiting amino acid in blue fox in the study of Dahlman et al. (2004). In the present trials, HIS supplementation did not affected growth, pelt size or pelt quality. However, the HIS supplementation in trial 1 barely increased the HIS content when comparing the groups $\mathrm{P} 16 \mathrm{M}$ vs. $\mathrm{P} 16 \mathrm{MH}$ (5.2 vs. $5.6 \mathrm{~g} \mathrm{~kg}^{-1} \mathrm{DM}$, respectively). The HIS levels were likely so similar as not to reveal any differences between diets. In trial 2, the difference in HIS content between diets P13M and P13MH was greater ( 3.8 vs $4.9 \mathrm{~g} \mathrm{~kg}^{-1} \mathrm{DM}$, respectively), but no difference in performance was detected. We concluded that HIS supply was sufficient in all the diets. In Dahlman's study (2004), the experimental diets were based on casein with extremely low-protein content, supplemented with crystalline amino acids and then sequentially deleted one at a time. In their study, the daily HIS intake was only $0.75 \mathrm{~g}$ in the diet lacking HIS. These types of experimental diets do not correspond to practical fox feeding, where such low HIS levels are not common since slaughter by-products are often abundant in HIS (Ahlstrøm et al. 2004). 


\section{Conclusions}

In this study, we found no adverse effects on pelt size or pelt quality in blue fox fed DCP $15 \%$ of ME diets. Blue foxes 20 weeks of age showed greater ADG and higher final body weight when fed DCP $21 \%$ of ME, but the effect diminished during the experimental period and could have been due to the higher ME intake of that group. Blue foxes 25 weeks of age showed no negative effects on growth, pelt size or pelt quality when fed DCP at levels $15 \%$ of ME. In this study, growth, pelt size and pelt quality were not affected by MET supplementation. We concluded that MET supply was sufficient or the experimental period was too short to reveal any differences. In this study, HIS supply was sufficient without HIS supplementation.

Our study showed that DCP $15 \%$ of ME was sufficient for blue fox in late growing-furring season. Dividing the growing-furring period from September 1 to pelting into two sections might be reasonable, as blue foxes did grow faster with protein levels over $15 \%$ of ME early in the period (October), but not in the latter part of it (November).

\section{References}

AOAC International 1995. Official Methods of Analysis. 16th ed. Association of Official Analytical Chemists International, Arlington, VA.

Ahlstrøm, Ø., Aldén, E., Børsting, C.F., Dahlman, T., Elnif, J., Hansen, N.E. ,Mäkelä, J., Pölönen, I. \& Skrede A. 2004. Handbok for fôrmidler til pelsdyr. Nordiske Jordbruksforskeres Forening. Subseksjon for pelsdjur. Rapport nr. 502. (in Norwegian).

Bellego, L. Le, van Milgen, J. , Dubois, S. \& Noblet, J. 2001. Energy utilization of low-protein diets in growing pigs. Journal of Animal Science 79: 1259-1271. https://doi.org/10.2527/2001.7951259x

Blomstedt, L. 1998. Pelage cycle in blue fox (Alopex lagopus): A comparison between animals born early and late in the season. Acta Agriculturae Scandinavica A: Animal Sciences 48: 122-128.

Boisen, S., Hvelplund, T. \& Weisbjerg, M.R. 2000. Ideal amino acid profiles as a basis for feed protein evaluation. Livestock Production Science 64: 239-251. https://doi.org/10.1016/S0301-6226(99)00146-3

Dahlman, T. 2003. Protein and Amino Acids in the Nutrition of the Growing-Furring Blue Fox. Helsingin yliopiston kotieläintieteen laitoksen julkaisuja. Helsinki 2003. 33 p.

Dahlman, T. 2007. Protein and amino acid requirements of the growing-furring blue fox (Alopex lagopus). CAB Reviews: Perspectives in Agriculture, Veterinary Science, Nutrition and Natural Resources 2: 089.

Dahlman, T., Kiiskinen, T., Mäkelä, J., Niemelä, P., Syrjälä-Qvist, L., Valaja, J. \& Jalava, T. 2002a. Digestibility and nitrogen utilisation of diets containing protein at different levels and supplemented with DL-methionine, L-methionine and L-lysine in blue fox (Alopex lagopus). Animal Feed Science and Technology 98: 218-235. https://doi.org/10.1016/S0377-8401(02)00029-9

Dahlman, T., Valaja, J., Niemelä, P. \& Jalava, T. 2002b. Influence of protein level and supplementary L-methionine and lysine on growth performance and fur quality of blue fox (Alopex lagopus). Acta Agriculturae Scandinavica - Section A: Animal Science 52: 174-182. https://doi.org/10.1080/090647002762381050

Dahlman, T., Valaja, J., Jalava, T. \& Skrede, A. 2003. Growth and fur characteristics of blue foxes (Alopex lagopus) fed diets with different protein levels and with or without DL-methionine supplementation in the growing-furring period. Canadian Journal of Animal Science 83: 239-245. https://doi.org/10.4141/A02-078

DahIman, T., Valaja, J., Venäläinen, E., Jalava, T. \& Pölönen, I. 2004. Optimum dietary amino acid pattern and limiting order of some essential amino acids for growing-furring blue foxes (Alopex lagopus). Animal Science 78: 77-86.

Finne, L. 2006. Rehusuositukset vuodelle 2006. Rehunvalmistajien luentopäivät, February 9-10 2006, Nokia, Finland. (in Finnish). Glem-Hansen, N. 1980. The Requirements for Sulphur Containing Amino Acids of Mink During the Growth Period. Acta Agriculturae Scandinavica 30:3 349-356. https://doi.org/10.1080/00015128009435280

Glem-Hansen, N. 1982. Utilization of L-Cystine and L- and D-Methionine by Mink during the Period of Intensive Hair Growth. Acta Agriculturae Scandinavica 32: 167-170. https://doi.org/10.1080/00015128209435746

Glem-Hansen, N. \& Hansen, N.E. 1981. Amino Acid Deposition in Mink during the Growth Period. Acta Agriculturae Scandinavica, 31: 410-414. https://doi.org/10.1080/00015128109435721

Gugołek, A., Wyczling, T., Janiszewski, P., Sobiech, P., Wyczling, P. \& Konstantynowicz, M. 2012. The Effect of Dietary Methionine Levels on the Performance Parameters of Arctic Foxes (Vulpes lagopus). Annals of Animal Science 12: 393-401. https://doi. org/10.2478/v10220-012-0033-3

Gugołek, A., Wyczling, T., Strychalski, J., Kowalska, D., Konstantynowicz, M. \& Zwoliński, C. 2017. Effect of diets with high methionine levels on growth performance, health status, nutrient digestibility and nitrogen retention in arctic foxes. Journal of Animal and Plant Sciences 27: 1743-1749.

Hansen, N.E., Finne, L. Skrede, A. \& Tauson, A.-H. 1991. Energiforsyningen hos mink ag ræv. Nordic Association of Agricultural Scientist, Nordic Association of Agricultural Scientists. Subsection for Fur Animals. Report No. 63. 59 p.

Lassén, T.M., Tauson, A.-H., Ahlstrøm, Ø., Rouvinen-Watt, K., Sandbøl, P., Koskinen, N. \& Christiansen, M. L.E. 2012. Annual cycle of body weight and metabolisable energy consumption and recommendations for metabolisable anergy provided by protein, fat and carbohydrate throughout the life cycle. In: Skrede, A. (ed.). Energy and main nutrients in feed for mink and foxes. Nordic Association of Agricultural Scientists. Subsection for Fur Animals. Nutrition and Feeding Committee. Report 63: 5-19. 
MTT 2006. Rehutaulukot ja ruokintasuositukset. MTT:n selvityksiä 106. Maa- ja elintarviketalouden tutkimuskeskus: Jokioinen. 84 p. (in Finnish).

NMKL 1991. Moisture and ash. Gravimetric determination in meat and meat products. NMKL, 3rd Ed. Nordic Committee on Food Analysis.

NMKL 2003. Nitrogen. Determination in foods and feeds according to Kjeldahl. NMKL, 4th Ed. Nordic Committee on Food Analysis. NRC 1982. Nutrient Requirements of Mink and Foxes. Second Revised Edition. Committee on Animal Nutrition. National Research National Academy Press, Washington, D.C. 72 p.

Puhakka, L., Jaakkola, S., Simpura, I., Kokkonen, T. \& Vanhatalo, A. 2016. Effects of replacing rapeseed meal with fava bean at 2 concentrate crude protein levels on feed intake, nutrient digestion, and milk production in cows fed grass silage-based diets. Journal of Dairy Science 99: 7993-8006. https://doi.org/10.3168/jds.2016-10925

Pullar, J.D. \& Webster, A.J. 1977. The energy cost of fat and protein deposition in the rat. British Journal of Nutrition 37: 355-363. https://doi.org/10.1079/BJN19770039

Rasmussen, P.V. \& Børsting, C.F. 2000. Effects of variations in dietary protein levels on hair growth and pelt quality in mink (Mustela vison). Canadian Journal of Animal Science 80: 633-642. https://doi.org/10.4141/A99-063

Rimeslåtten, H. 1976. Experiments in feeding different levels of protein, fat and carbohydrates to blue foxes. In: Proceedings of the I International Scientific Congress in Fur Animal Production, 27.-29.4.1976, Helsinki, Finland. Scientifur Introduction Issue: 28-30.

Sandbøl, P., Clausen, T.N. \& Hejlesen, C. 2004. Ideal Protein for Mink (Mustela vison) in the growing and furring periods. In: Urlings, B., Spruijt, B., Ruis, M. \& Boekhorst ,L. (eds.). Proceedings of the VIII International Scientific Congress in Fur Animal Production, September 15-18 2004, Hertogenbosch, Netherlands. Scientifur 28: 120-123.

Tauson, A.-H. 2012. Energy requirement and utilization in fur animal production. In: Skrede, A. (ed.). Energy and main nutrients in feed for mink and foxes. Nordic Association of Agricultural Scientists. Subsection for Fur Animals. Nutrition and Feeding Committee. Report No. 63: 21-46.

Työppönen, J., Valtonen, M. \& Berg, H. 1986. Low-protein Feeding in Mink: Effects on plasma free amino acids, clinical blood parameters, and fur quality. Acta Agriculturae Scandinavica 36: 421-428. https://doi.org/10.1080/00015128609439899

Ylinen, V., Pylkkö, P., Peura J., Tuomola, E. \& Valaja, J. Nutrient digestibility and nitrogen utilization in blue fox fed of low-protein diets supplemented with DL-methionine and L-histidine. Manuscript. 